Bangladesh J. Plant Taxon. 23(2): 215-222, 2016 (December)

(C) 2016 Bangladesh Association of Plant Taxonomists

\title{
PALYNOLOGICAL STUDY OF SOME IRANIAN SPECIES OF SCABIOSA L. (CAPRIFOLIACEAE)
}

\author{
Ebadi-Nahari Mostafa ${ }^{1}$ and Nikzat-Siahkolaee Sedigheh $^{2}$ \\ Department of Biology, Faculty of Science, Azarbaijan Shahid Madani University, Tabriz, Iran \\ Keywords: Caprifoliaceae; Pollen characters; Scabiosa; SEM; Taxonomy; UPGMA.
}

\begin{abstract}
The pollen morphology of six species of Scabiosa L. (Caprifoliaceae) from Iran has been examined by scanning electron microscopy (SEM). Pollen grains were tricolpate in $S$. columbaria and triporate in the rest studied species. Two types of exine ornamentation were revealed: spinulate and gemmate. The pollen shape in polar view varied from triangular to circular among investigated taxa. Statistical analysis showed that some quantitative morphological features such as polar axis (P), equatorial axis (E) and aperture diameter were main characters in identification of the taxa studied. These taxa were separated from each other using cluster analysis and placed within two clusters. Our result based on UPGMA analysis is in agreement with morphological classification and recent findings on taxonomic position of the Scabiosa.
\end{abstract}

\section{Introduction}

Scabiosa L. belonging Caprifoliaceae includes approximately 80 annual or perennial herbs, distributed in Europe and the Mediterranean Basin, southern Africa and eastern Asia (Reveal and Chase, 2011). Some of the species are known as a source of herbal medicine for the treatment of many human diseases (Bonet et al., 2007). Few Scabiosa species are cultivated as ornamental plants.

Linnaeus (1753) distinguished three genera that include Scabiosa L., Dipsacus L. and Knautia L. Later on, Scabiosa sensu Linnaeus was segregated into different genera: Pterocephalus Adans, Succisa Haller, Cephalaria Schrad. ex Roem \& Schult. After remaining species of Scabiosa in different sections, were raised to new genera: Lomelosia Raf, Sixalis Raf, Pseudoscabiosa Devesa, Pterocephalidium G. Lopez (Greuter and Raus, 1985; Adanson, 1763; Haller, 1768; Devesa, 1984a, b; Lopez-Gonzales, 1987). Rechinger and Lack (1991) did not accept the nomenclatural changes suggested by Greuter and Raus (1985). Jamzad (1993) maintained a traditional and broad concept of genus Scabiosa too.

Taxonomic problems and species complexity are very common in this genus. Hybridization is common and, as a result, the number of reported species (and subspecies) has widely varied (Bobrov, 1957; Grossman, 1975; Jasiewicz, 1976).Since taxonomic position of some species is ambiguous, finding various remarkable characters will be useful to determine the taxonomic status of species. Pollen morphology has been able to reposition several disputed genera and interpret problems related to the origin and evolution of many taxa (Nair, 1980) and to derive classification of angiosperms (Cronquist, 1981).

Pollen morphology of this family has been studied by various authors (Ting, 1949; Nowicke and Skvarla, 1979; Feng et al., 2000). Erdtmann (1952) studied 35 genera of Dipsacaceae, and results showed the presence of two types of pollen apertures in this family: porate and colpate.

\footnotetext{
${ }^{1}$ Corresponding author , Email: ebadi2023@yahoo.com

${ }^{2}$ Faculty of Biological Sciences, Shahid Beheshti University, Tehran, Iran. Email: Nikzat.sedighe@gmail.com
} 
Caputo and Cozzolino (1994) divided Dipsacaceae into two major clades based on morphological and palynological characters. Khalik (2010) studied various genera of Dipsacaceae and proved the taxonomic value of pollen characters. Pollen shape, size, exine ornamentation, number and features of apertures represent useful characters for distinguishing among species.

There are 22 species of Scabiosa recorded in the Flora Iranica (Rechinger, 1989) that species are divided into two subgenera (Scabiosa and Asterocephalus) and three sections including Scabiosa, Asterocephalus and Olivierianae. Greuter and Raus (1985) treated Iranian species of Scabiosa into two genera as Lomelosia (= Scabiosa sect. Astrocephalus and sect. Olivierinae) and Scabiosa s. str. (Scabiosa s. l sect. scaboisa).

The taxonomic grouping of the genera Scabiosa and Lomelosia is exactly unknown (Mayer and Ehrendorfer, 1999). For example on the basis of The plant list (2013), situation of many Iranian species is unresolved (L. flavida, L. calocephala, L. bicolor, L. esfandiarii, $L$. prophyroneura, L. schimperiana, L. machrochaete, L. kermanensis and L. leucactis) and some of them are accepted names as Scabiosa (S. rotata, S. micrantha, S. argentea). As well as, $L$. caucasica and L. olivieri accepted as genus Lomelosia and S. persica and S. columbaria accepted as genus Scabiosa.

As the circumscription of these groups are not obvious completely and it has not been stabilized yet, in this work only the genus Scabiosa sensu Rechinger and Lack (1991) has been subject of studies.

There are no reports on pollen morphology of the Scabiosa from Iran. The present study aims to survey the pollen morphology of six Iranian species of Scabiosa L. (belonging to three sections) as S. columbaria L., S. micrantha Desf., S. persica Boiss., S. calocephala Boiss., S. olivieri Coult. and S. flavida Boiss. \& Hausskn. using scanning electron microscopy and evaluating its significance in taxonomy of the genus.

\section{Materials and Methods}

The plant samples for the study were collected from natural populations in different regions of Iran during spring and summer of 2013. Four to five individuals were collected randomly from each locality. Details of localities are given in Table 1 . The voucher specimens were deposited in Herbarium of Shahid Beheshti University (HSBU).

Table 1. Localities and voucher numbers of the taxa studied.

\begin{tabular}{llll}
\hline Genus & Species & Locality & Voucher No. \\
\hline Scabiosa L. & S. columbaria L. & Mazandaran, Siahbisheh & HSBU4004 \\
& S. micrantha Desf. & North Khorasan, 45 km of Bojnurd & HSBU4005 \\
& S. persica Boiss. & West Azarbaijan, Piranshahr & HSBU4000 \\
& S. alocephala Bioss. & Tehran, SorkhHesar Park & HSBU4001 \\
& S. olivieri Coult. & Tehran, Telo & HSBU4003 \\
& S. flavida Boiss. \& & North Khorasan, 45 km East of Bojnurd & HSBU4002 \\
& Hausskn & & \\
\hline
\end{tabular}

For SEM, pollen samples were mounted on stubs using double-sided adhesive tape. Macro and microphotographs which showed general view of pollen surface were taken by Phenomprox SEM at an accelerating voltage $10.0 \mathrm{kV}$. For measurements "Image Tools ver. 3.00" software with high degree of accuracy and confidence was used. Some palynological characteristics, such as 
equatorial diameter $(E)$, polar axis length $(P), P / E, \log P / E$, exine ornamentation and pore dimensions, were described for each sample.

In order to show relationships of species, we performed a cluster analysis based on Euclidean Distances with un-weighted pair-group method with arithmetical mean (UPGMA) method by using the program PAST ver. 2.17c (Hammer et al., 2001).

\section{Results}

Palynological characters were randomly measured by using minimum 20 pollen grains. The quantitative and qualitative palynological data of six investigated taxa were shown in Table 2.

Table 2. Evaluated pollen characters in the studied taxa.

\begin{tabular}{|c|c|c|c|c|c|c|}
\hline & S. columbaria & S. micrantha & S. persica & S. calocephala & S. olivieri & S. flavida \\
\hline Pollen type & Tricolpate & Triporate & Triporate & Triporate & Triporate & Triporate \\
\hline Polar axis $(\mathrm{P})$ & $80.71 \pm 3.24$ & $28.44 \pm 2.86$ & $27.01 \pm 2.02$ & $22.04 \pm 2.46$ & $93.55 \pm 4.12$ & $90.32 \pm 3.59$ \\
\hline $\begin{array}{l}\text { Equatorial axis } \\
\text { (E) }\end{array}$ & $58.07 \pm 5.23$ & $68.26 \pm 3.61$ & $98.42 \pm 4.82$ & $87.65 \pm 4.46$ & $121.39 \pm 6.13$ & $117.44 \pm 5.15$ \\
\hline$(\mathrm{P} / \mathrm{E})$ & 1.38 & 0.41 & 0.27 & 0.25 & 0.77 & 0.76 \\
\hline Pollen shape & Prolate & Preoblate & Preoblate & Preoblate & Suboblate & Suboblate \\
\hline Polar view & Circular & $\begin{array}{l}\text { Circular- } \\
\text { triangular }\end{array}$ & Triangular & Triangular & $\begin{array}{l}\text { Circular- } \\
\text { triangular }\end{array}$ & $\begin{array}{l}\text { Circular- } \\
\text { triangular }\end{array}$ \\
\hline Aperture & Linear & Circular & Elliptic & Elliptic & Circular & Circular \\
\hline $\begin{array}{l}\text { Aperture } \\
\text { diameter }\end{array}$ & $40.67 \pm 2.96$ & $14.33 \pm 1.27$ & $15.69 \pm 1.56$ & $15.19 \pm 2.05$ & $15.02 \pm 0.92$ & $15.89 \pm 1.08$ \\
\hline $\begin{array}{l}\text { Exine } \\
\text { ornamentation }\end{array}$ & $\begin{array}{l}\text { Spinulate- } \\
\text { Spinuloid }\end{array}$ & $\begin{array}{l}\text { Spinulate- } \\
\text { Spinuloid }\end{array}$ & $\begin{array}{l}\text { Gemmate- } \\
\text { Spinuloid }\end{array}$ & $\begin{array}{l}\text { Gemmate- } \\
\text { Spinuloid }\end{array}$ & $\begin{array}{l}\text { Spinulate- } \\
\text { Spinuloid }\end{array}$ & $\begin{array}{l}\text { Spinulate- } \\
\text { Spinuloid }\end{array}$ \\
\hline
\end{tabular}

There are two major types of pollen grain apertures. It varies from tricolpate in S. columbaria to triporate in the rest studied species (Fig1) as S.persica and S. calocephala have elliptical pore and S. micrantha, S. flavida and S. olivieri have circular pores (Table 2).

The size of the pollen grain of studied taxa ranged from $28 \times 68 \mu \mathrm{m}(P \times E)$ in S. micrantha to $93 \times 121 \mu \mathrm{m}(P \times E)$ in S. olivieri. The ratio between the mean polar axis $(P)$ and the mean equatorial diameter $(E)$ can be used to assign the pollen grains to shape classes as of Erdtmann (1952). The shape of the pollen grain in equatorial view varied from preoblate to prolate among investigated taxa. The pollen shape in polar view varied from triangulate in S. persica and $S$. calocephala, circular in S. colembaria to circular-triangular in the rest of the species (Fig. 1).

Two types of exine ornamentation found in studied taxa. Gemmate type was observed in $S$. persica and $S$. calocephala as so that, between the gemmate are numerous low irregularly spaced spinuloid (Fig 2). Spinulate type was observed in S. colembaria, S. flavida, S. micrantha and S. olivieri as beset with numerous similar small conical spinuloid (Fig. 2).

The taxa investigated were separated from each other in a UPGMA tree (Fig. 3). Cluster analysis showed that species placed in two clusters. S. olivieri and S. flavida placed in one cluster and the remained taxa placed in other cluster. This cluster divided to two sub-clusters: subcluster I included S. micrantha, S. persica and S. calocephala and subcluster II contained S. columbaria.

Principal component analysis (PCA) shows that the polar axis (P), equatorial axis (E) and aperture diameter are main characters in grouping of species (Fig. 4). 

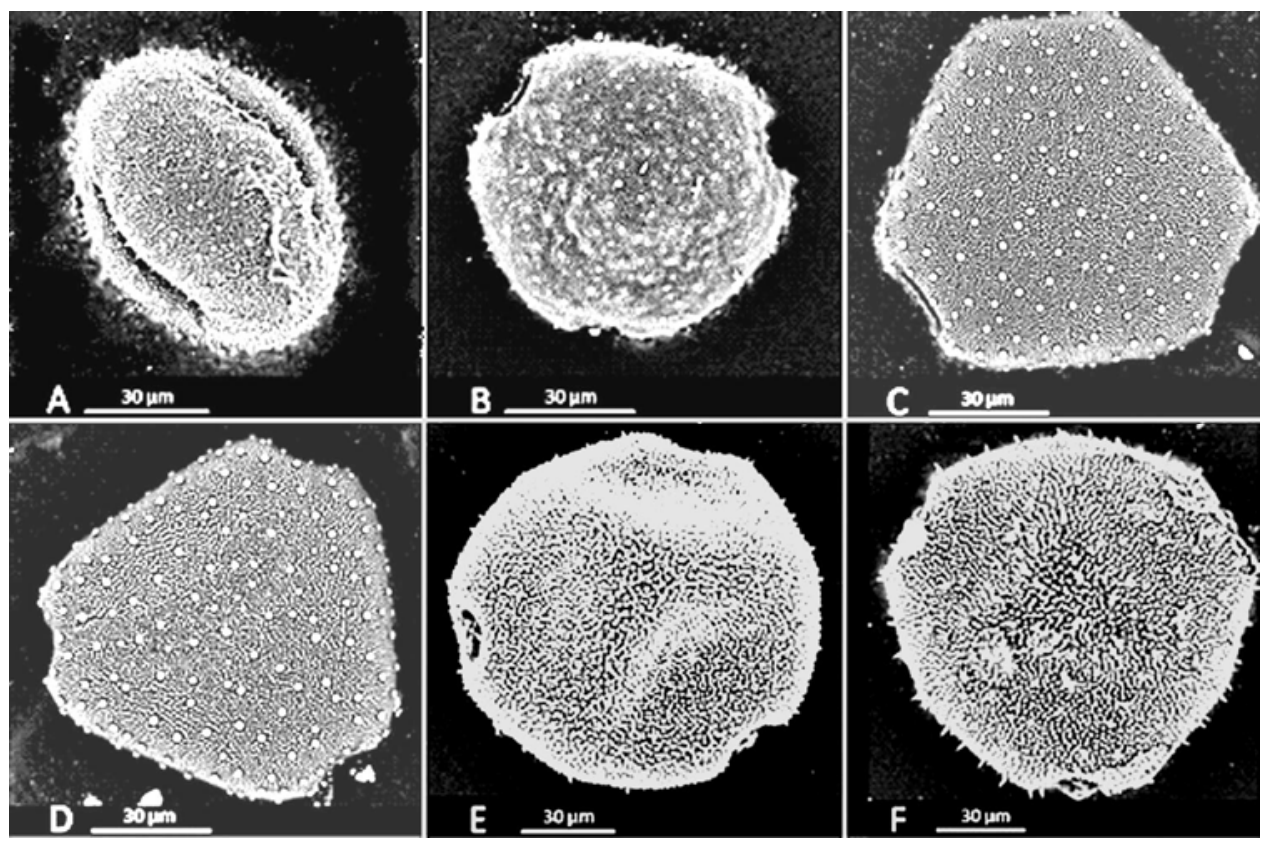

Fig. 1. Pollen electron micrograph of studied taxa. A: S. columbaria, B: S. micrantha, C: S. persica, D: S. calocephala, E: S. olivieri and F: S. flavida.
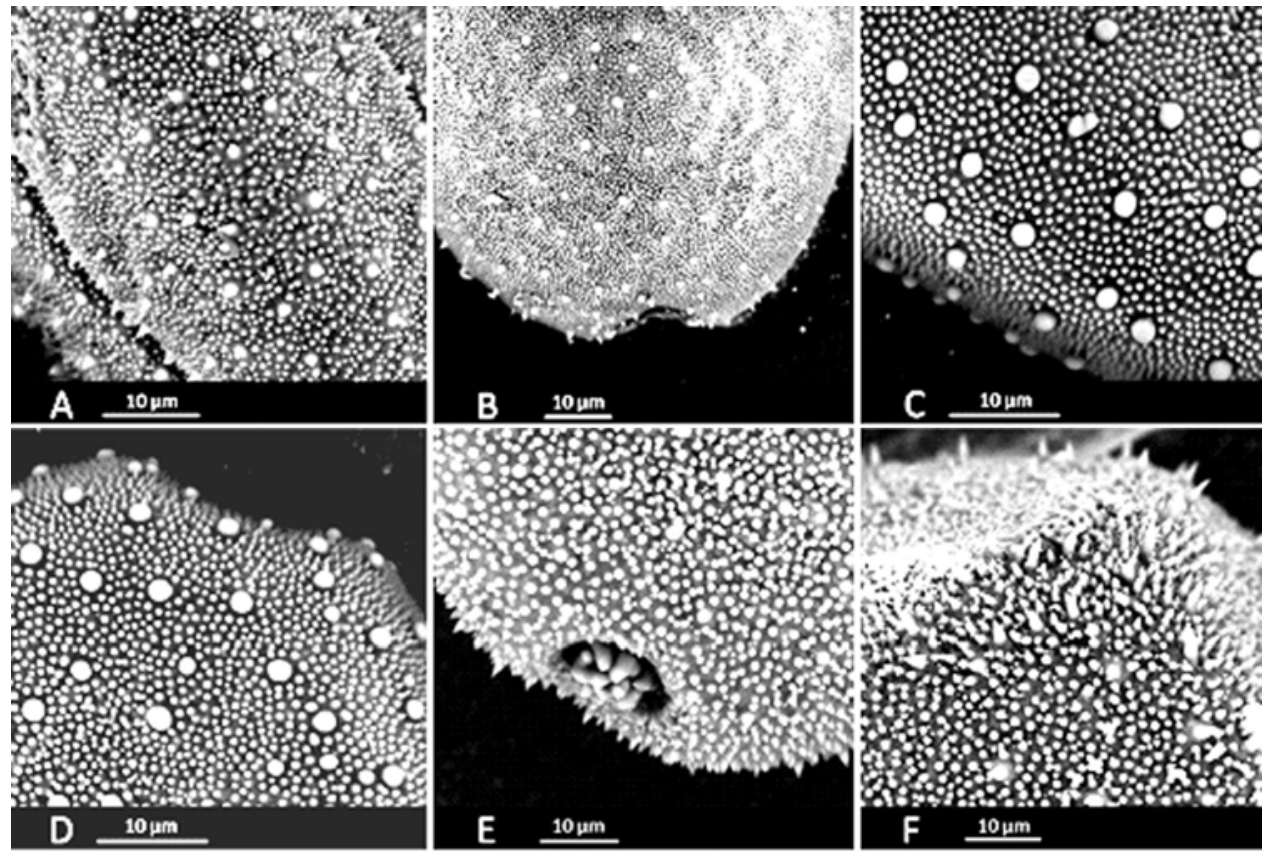

Fig. 2. Pollen surface ornamentations in studied taxa. A: S. columbaria, B: S. micrantha, C: S. persica, D: S. calocephala, E: S. olivieri and F: S. flavida. 


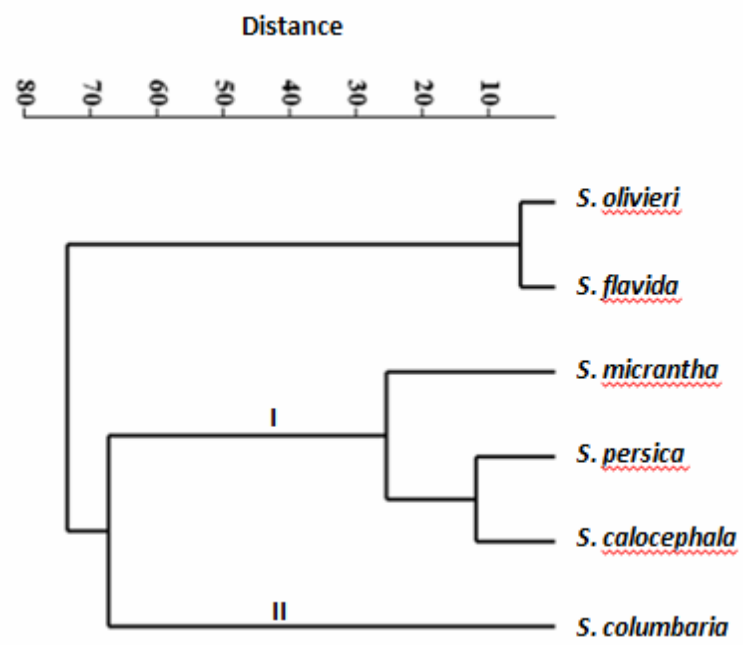

Fig. 3. UPGMA dendrogram showing the relationship among studied Scabiosa species based on palynological characters.

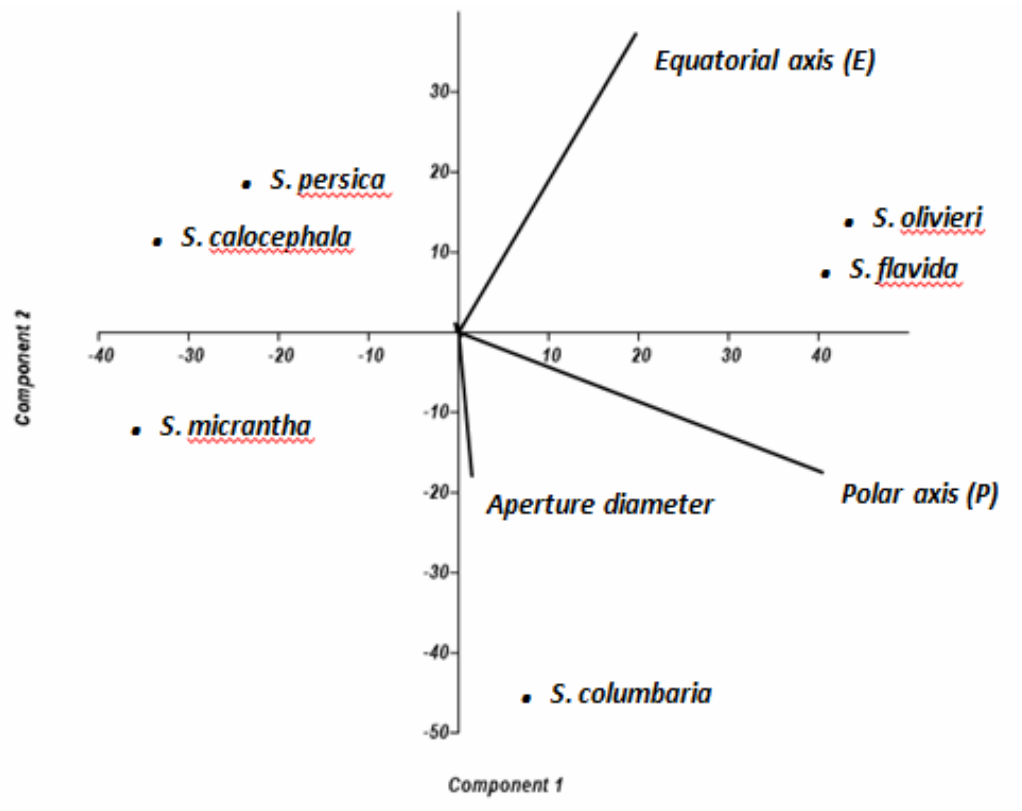

Fig. 4. Principal Component Analysis (PCA) among the studied Scabiosa species based on palynological characters.

\section{Discussion}

There are lots of debates on taxonomy of the genus Scabiosa and undoubtedly the genus has been the subject of the various taxonomic studies. Taxonomic classification of Scabiosa species is still unresolved. Because of morphological similarities between Scabiosa species are very high, so it seems that the application of pollen morphology can help us to resolve the taxonomical 
problems between the species. Previous studies show that pollen characters can be used for solving taxonomic problems (Khalik, 2010). In this study, palynological characters varied among the investigated taxa and were useful in identification of taxa. For example, $S$. columbaria can be distinguished from the other taxa based on aperture types. $P / E$ ratio was useful in identification of S. micrantha from S. olivieri and S. flavida, where their exine ornamentation is very similar.

Various palynological studies on different species of the Dipsacaceae have confirmed that pollen characters were important to species identification. Perveen and Qaiser (2011) studied palynological characteristic in some species of Dipsacaceae from Pakistan. Their results indicated that pollen characters may be used to delimit the species.

Aperture types are the most significant pollen characters. On the basis of aperture types, Scabiosa is divided into two pollen types including tricolpate and triporate. S. columbaria was tricolpate while the rest studied taxa were triporate. Scabiosa is divided into two subgenera, including Scabiosa and Asterocephalus, based on morphological characters (such as presence of Groove or pit on epicalyx tube) (Rechinger, 1989) and according to present study, they have tricolpate and triporate apertures, respectively. Perveen and Qaiser (2011) divided the Pakistani species of the family Dipsacaceae into three pollen types on the basis of aperture viz., Dipsacus inermis-type, Pterocephalus gedrosiacus-type and Scabiosa candollei-type. Our results are in agreement with those of Perveen and Qaiser (2011) who have also observed triporate pollen in Pakistani Scobiosa species. S. columbaria species complex has long posed for a complex taxonomic issue. Hybridization is common and, as a result, the number of reported species (and subspecies) has varied widely (Bobrov, 1957; Grossman, 1975; Jasiewicz, 1976). A revision of the species limits in S. columbaria is much needed.

The UPGMA dendrogram based on palynological characters is in concordant with morphological classification. Mayer and Ehrendorfer (1999) investigated differentiation of the epicalyx, the corona, the epi-diaphragm, calyx, pollen, chromosome number and their taxonomic importance in genus Scabiosa s.l and concluded that these features could be helpful in circumscribing of this genus.

S. persica and $S$. calocephala have similar characters including: number of corona vein, epicalyx tube pits (oblong shape), presence of sulcus between pits, hidden bristle rather to corona. These two species are different in leaves, leaflets, number of involucre bracts (Jamzad, 1993).

S. olivieri and S. flavida have small dipsacaceous- head and thus they are different from other species. These two species have triangle pits, short corona, evident bristles rather to corona, lack of sulcus between pits. There is radiant flower in S. flavida but not in S. olivieri.

S. micrantha have oval shape dipsacaceous- head in contrast with other species. This specieshas oblong shape pits, sulcus between pits, and evident bristles rather to corona.

Despite other species (five above mentioned species), S. columbaria has 8-grooves along epicalyx tube (Jamzad, 1993). Morphological similarity between these taxa is approved by pollen characteristics (Fig 3). S. micrantha have some characters of S. olivieri group (S. olivieri and S. flavida) and some of $S$. persica group ( $S$. persica and $S$. calocephala). Hence, on the basis of pollen features, $S$. micrantha located between them.

Taxonomic status of $S$. calocephala is unresolved but some data suggest that it is synonymous with Lomelosia calocephala. S. calocephala and S. micrantha based on the presence of pits on epicalyx tube, are placed in sect. Asterocephalus. The UPGMA dendrogram showed that this species were very similar to $S$. persica. Therefore, taxonomic status of $S$. calocephala does not change according to pollen morphology.

S. olivieri and S. flavida were previously classified within the genus Scabiosa, based on the calyx characters (Tackholm, 1974; Rechinger, 1989; Boulos, 2000). Mayer and Ehrendorfer 
(1999) separated all species of Scabiosa set. Olivierianae into Lomelosia. In general, our results agree with those of Mayer and Ehrendorfer. Caputo et al. (2004) studied phylogenetic relationships among 17 species of Dipsacaceae and they divided Dipsacaceae into two major clades: one including Lomelosia and Pycnocomon, both in a sister group relationship with a clade including Scabiosa, Sixalix and Pterocephalus, and the other including the rest of species.

Unlike other studies, in this work exine ornamentation was not useful to distinguish among closely related genera such as Scabiosa and Lomelosia. The exine ornamentation of S. micrantha is very similar to $S$. olivieri and $S$. flavida while our results showed that $S$. micrantha was grouped in sect. Asterocephalus in accordance with Flora Iranica classification.

Feng et al. (2000) studied pollen of 17 species of the genus Dipsacus and divided the genus into three pollen types based on exine ornamentation viz., dispinulate-reticulate, spinulatefoveolate and dispinulate or rarely smooth. He further reported that pollen morphology was little helpful at specific level.

The results of this study showed that pollen morphology provided facile and reliable characters for taxonomic studies of Scabiosa.

\section{References}

Adanson, M. 1763. Familles des plantes. Vincent, Paris. 2: 152.

Bobrov, E.G. 1957. Dipsacaceae. In: Flora of the USSR, Vol. 24 (Ed. by B.K. Shishkin). Akademii Nauk SSSR, Moscow.

Bonet, M.A. and Vallès, J. 2007. Ethnobotany of Montseny biosphere reserve (Catalonia, Iberian Peninsula): plants used in veterinary medicine. Journal of Ethnopharmacology 110(1):130-147.

Boulos, L. 2000. Flora of Egypt. 2. Cairo.

Caputo, P. and Cozzolino, S. 1994. A cladistics analysis of Dipsacaceae (Dipsacales). Plant System.Evol. 189: 41-61.

Caputo, P., Cozzolino, S. and Moritti, A. 2004. Molecular phylogenetics of Dipsacaceae reveals parallel trends in seed dispersal syndromes. Plant System. Evol. 246: 163-175.

Cronquist A. 1981. An Integrated System of Classification of Angiosperms. Columbia University Press, New York.

Devesa, J. A. 1984a. Revisidn del genero Scabiosa en la Peninsula Ibrrica e Islas Baleares. Lagascalia. 12: 143-212.

Devesa, J. A. 1984b. Pseudoscabiosa, genero nuevo de Dipsacaceae. Lagascalia 12: 213-221.

Erdtmann, G. 1952. Pollen morphology and plant taxonomy. Chronica Botanica Co., Massachusettes; Copenhagen.

Feng, X.F., Ai, T.M. and Xu, H.N. 2000.A study on pollen morphology of Dipsacus. Zhongguo Zhong Yao ZaZhi. 25(7): 394-401.

Greuter, W. and Raus, T. 1985. Conservatoire et Jardinbotaniques de la Ville de Gene`ve, Gene`ve. MedChecklist Notulae: 11. Willdenowia 15: 61-64.

Grossman, F. 1975. Morphologisch-o“kologischeUntersuchungenan Scabiosa columbaris L. s.l. immittleren und westlichen Alpengebiet. Vero"ffentlichungen des Geobotanischen Institutes der ETH, Stiftung Rübel. 25: 1-125.

Haller, A. 1768. Historiastirpiumindigenarum Helvetiae, Societatis Typhographicae, Bern. 1: 87.

Hammer Ø, Harper DAT, Ryan PD. 2001. PAST: Paleontological Statistics Software Package for Education and Data Analysis. Palaeontologia Electronica 4: 9. http://palaeo-electronica.org/ 2001_1/past/issue1 _01.htm.

Jamzad, Z. 1993. Scabiosa L. In: Assadi, M., Khatamsaz, M. and Maassoumi, A.A. (Eds.) Flora of Iran, Vol. 8. Islamic Republic of Iran, Ministry of Jahad-e Sazandegi, Research Institute of Forests and Rangelands, Tehran, pp. 63-106. 
Jasiewicz, A. 1976. Scabiosa. In: T.G. Tutin, V.H. Heywood, N.A. Burges, D.H. Valentine, S.M. Walters and D.A. Webb (Eds). Flora Europaea, Vol. 4. Cambridge University Press, Cambridge, pp. 68-74.

Khalik, K.A. 2010. A palynological study of the family Dipsacaceae in Egypt and its taxonomic significance. J. Bot. Taxonomy \& Geobotany 121(3-4): 97-111.

Linnaeus, C. 1753. Species plantarum, exhibentesplantas rite cognitas, ad genera relatas, cum Differentiis Specificis, Nominibus Trivialibus, Synonymis Selectis,Locis Natalibus, Secundum systema sexualedigestas, Impensis Laurentii Salvii, Stockholm 1: 98.

Lopez-Gonzalez, G. 1987. Pterocephalidium, unnuevogrneroibrrico de la familia Dipsacaceae. Anales Jard. Bot. Madrid. 43: 245-252.

Mayer, V. and Ehrendorfer, F. 1999. Fruit differentiation, palynology, and systematics in the Scabiosa group of genera and Pseudoscabiosa (Dipsacales). PI. Syst. Evol. 216: 135-166.

Nair, P.K.K. 1980. Pollen Morphology of Angiosperms.Vikas Publications, New Delhi.

Nowicke, J.W. and Skvarla, J.J. 1979. Pollen morphology: The potential influence in higher order systematics. Ann. Mo. Bot. Gard. 66: 633-699.

Perveen, A. and Qaiser, M. 2011. Pollen flora of Pakistan-Dipsacaceae LXVIII., Pak. J. Botany 42(6): 28252827.

Rechinger, K. H. 1989: Scabiosa sect. Olivierianae, sect. nova (Dipsacaceae). Willdenowia 19: 137-151.

Rechinger, K. H and Lack, H. W. 1991. Dipsacaceae. In: Rechinger, K. H., (Ed.): Flora Iranica. 168, pp. 167.

Reveal, J. L. and Chase, M. W. 2011. APG III: Bibliographical information and synonymy of Magnoliidae. Phytotaxa 19: 71-134.

Tackholm, V. 1974. Students’ Flora of Egypt. Beirut, Cairo University.

The Plant List 2013. Version 1.1. Published on the Internet; <www.theplantlist.org>.accessed 1st January.

Ting, S.U. 1949. Illustration of pollen grains of some Chinese plants. Bot. Notiser. 4: 277-282. 